\title{
KAJIAN YURIDIS PERATURAN HUKUM MENGENAI ASPEK TRANSPARANSI TERHADAP RISIKO INVESTASI LAYANAN PRIORITY BANKING
}

\author{
Renny Utaminingsih Harsanto \\ Program Magister Ilmu Hukum, Universitas Katolik Parahyangan Bandung \\ email: rennyutami91@gmail.com
}

disampaikan 29/07/2019 - di-review 19/11/2019 - diterima 03/12/2020

DOI: $10.25123 /$ vej.3381

\begin{abstract}
.
One of the new and innovative products offered in context of priority banking services is investment products. This research shall have a look at the transparency aspect of the risk management of this particular bank product offered to priority customers and will be conducted by a juridical normative method. In addition, the author also interviewed a number of key informants working in the banking industry at Bandung. The legal analysis conducted shows that while quite a number of rules and regulation in regard to risk management of bank investment products exist and are put in place, what it lacks, in terms of customer protection, is transparency.
\end{abstract}

Keywords:

Priority Banking, Service, Transparency, Risk management, bank investment product

\begin{abstract}
Abstrak
Salah satu layanan Priority Banking adalah produk investas yang merupakan inovasi. Penelitian ini akan menelaah aspek transparansi dari pengelolaan risiko produk layanan prioritas ini. Metoda yang digunakan untuk menelaah aspek ini adalah yuridis normatif. Peraturan perundangundangan yang terkait dengan perbankan dan produk-produknya akan ditelaah. Informasi tentang ini juga diperoleh dari wawancara yang dilakukan dengan mereka yang berkecimpung di bisnis perbankan di Bandung. Ditenggarai bahwa sekalipun ditemukan banyak aturan perihal pengaturan-pengendalian risiko berkaitan dengan produk investasi yang ditawarkan perbankan pada nasabah prioritas, aspek transparansi masih kurang terperhatikan.
\end{abstract}

Kata kunci: layanan perbankan prioritas, transparansi, manajemen risiko, produk investasi perbankan

\section{Pendahluan}

Perbankan merupakan lembaga intermediasi keuangan atau financial intermediary, yakni badan usaha yang melakukan kegiatan menghimpun dana dari masyarakat dalam bentuk simpanan dan menyalurkannya kembali kepada masyarakat lain yang membutuhkan dalam bentuk kredit atau pembiayaan dan memberikan jasa dalam lalu lintas pembayaran. ${ }^{1}$ Dari pengertian tersebut, secara sederhana dapat disimpulkan bahwa bank adalah suatu badan usaha yang

1 Hermansyah, Hukum Perbankan Nasional Indonesia, Edisi Kedua, Kencana Prenada Media Group, Jakarta, 2005, hlm., 8 
berbadan hukum yang bergerak di bidang jasa keuangan. Bank sebagai Badan Hukum secara yuridis adalah merupakan subyek hukum yang berarti dapat mengikatkan diri dengan pihak ketiga. ${ }^{2}$

Keberadaan perbankan di Indonesia semakin banyak hal tersebut dapat dilihat dengan hadirnya bank-bank baru tumbuh dan berkembang, dana yang berhasil dihimpun dari masyarakat pun merupakan catatan keberhasilan perbankan. Jumlah dana yang dapat dihimpun oleh suatu bank merupakan pencerminan dari meningkatnya kepercayaan masyarakat terhadap bank. Oleh karena itu, bank sebagai lembaga keuangan yang mengelola dana-dana masyarakat, sangat dituntut keahliannya untuk mengelola usaha ini, karena bila kepercayaan masyarakat kurang terhadap lembaga ini masyarakat akan berlomba menarik dana yang disimpan di bank, dampak yang lebih jauh bisa dilihat kegiatan perekenomian tidak berjalan sebagaimana mestinya. ${ }^{3}$ Hal ini berarti kehadiran Bank sebagai suatu badan usaha tidak semata-mata bertujuan bisnis, namun ada misi lain, yakni peningkatan kesejahteraan masyarakat pada umumnya. ${ }^{4}$ Fungsi bank sebagai Lembaga intermediasi terutama dalam hal kegiatan penyaluran kredit mempunyai peranan penting bagi pergerakan perekenomian secara keseluruhan dan memfasilitasi pertumbuhan ekonomi. Selain itu, fungsi intermediasi juga dapat digunakan untuk mengukur tingkat efisiensi perbankan yang merupakan salah satu indikator untuk menganalisa kinerja (performance) suatu bank dan juga sebagai sarana untuk lebih meningkatkan efektifitas kebijakan moneter. ${ }^{5}$

Pengertian perbankan diatur dalam Pasal 1 Ayat 1 Undang-Undang Nomor 7 Tahun 1992 sebagaimana telah diubah dengan Undang-Undang Nomor 10 Tahun 1998 Tentang Perbankan (selanjutnya disebut sebagai UU Perbankan) yang menjelaskan bahwa perbankan adalah segala sesuatu yang menyangkut tentang

\footnotetext{
Sentosa Sembiring, Hukum Perbankan, Mandar Maju, Bandung, 2008, hlm., 2

Id, hlm., 8.

Id.

Renniwaty Siringoringo, Analisis Fungsi Intermediasi Perbankan Indonesia (Studi Kasus Bank Umum Konvesional yang Tercatat di BEI Periode 2012-2016), Jurnal Inspirasi Bisnis \& Manajemen Vol 1 (2) 2017, 135-144, hlm., 136, 2017
} 
bank, mencakup kelembagaan, kegiatan usaha, serta cara dan proses dalam melaksanakan kegiatan usahanya.

Perkembangan dunia perbankan saat ini tidak hanya sebatas pada menyimpan dan menyalurkan dana dalam bentuk pemberian kredit. Pada dasarnya, Pasal 6 UU Perbankan menjelaskan bahwa usaha perbankan tidak hanya sebatas pada pemberian kredit, namun usaha bank meliputi antara lain menerbitkan surat pengakuan hutang; membeli, menjual atau menjamin atas risiko sendiri maupun untuk kepentingan dan atas perintah nasabahnya; dan melakukan kegiatan lain yang lazim dilakukan oleh bank sepanjang tidak bertentangan dengan Undang-Undang ini dan peraturan perundang-undangan yang berlaku.

Layanan jasa yang diberikan oleh bank sebagaimana dijelaskan dalam Pasal 6 UU Perbankan, terlihat bahwa usaha bank semakin luas dalam arti tidak hanya memberi kredit. Dalam Pasal 6 huruf M UU Perbankan, pasal tersebut dapat memberi ruang sehingga bank bisa melalukan layanan/kegiatan perbankan di luar yang telah ditentukan dalam Pasal 6 UU Perbankan, namun harus tetap sesuai dengan peraturan hukum yang berlaku. Untuk itu pengelola bank harus melakukan terobosan dalam memberikan layanan jasa perbankan, tidak hanya bersifat pasif akan tetapi harus bersifat aktif namun tidak menyimpang dari asas pengelolaan bank, yakni prinsip kehati-hatian (prudential banking).

Atas dasar adanya Pasal 6 huruf M tersebut, maka pada perkembangannya inovasi layanan bank dalam menyediakan produk dan/atau aktivitas perbankan pun semakin meluas. Semakin berkembangnya inovasi layanan bank dalam menyediakan produk dan/atau aktivitas tersebut yang disesuaikan dengan kebutuhan nasabah mendorong adanya suatu segmen nasabah tertentu yang menginginkan bank dapat memberikan layanan perbankan secara lebih personal dan mendapatkan tambahan layanan keistimewaan tertentu. Hal ini pun berdampak semakin banyak bank di Indonesia yang memberikan Layanan Nasabah Prima (selanjutnya disebut sebagai "LNP") atau Nasabah Prioritas yang lebih banyak dikenal sebagai layanan Priority Banking. Pada dasarnya, Layanan Nasabah Prima adalah bagian dari kegiatan usaha bank dalam menyediakan 
layanan terkait produk dan/atau aktivitas dengan keistimewaan tertentu bagi nasabah prima.

Dengan adanya Layanan istimewa yang diberikan oleh bank kepada nasabah dalam bentuk Layanan Priority Banking ini telah menciptakan suatu inovasi produk perbankan karena dalam layanan ini tidak hanya menawarkan produk perbankan berupa simpanan saja, tetapi juga menawarkan produk investasi. Produk investasi yang sangat diminati oleh nasabah adalah investasi dalam bentuk reksadana, obligasi, dan transaksi valuta asing. Produk investasi tidak langsung yang terkenal adalah reksadana (mutual funds). Produk investasi ini merupakan produk yang sangat diminati oleh Nasabah Priority Banking. Dengan reksadana ini investor menyerahkan sejumlah uang kepada perusahaan reksadana yang bertindak sebagai manajer investasi untuk diinvestasikan ke dalam berbagai jenis sekuritas seperti dalam bentuk Deposito, Sertifikat Bank Indonesia, Obligasi, Saham atau kombinasi antara keempatnya. Untuk itu, investor menerima konfirmasi penyertaannya disertai dengan jumlah unit penyetaraannya. Evaluasi, analisis, pemulihan, pengalokasian dana ke berbagai sekuritas dijalankan oleh perusahaan reksadana dan hal ini dijelaskan secara transparan dalam prospektus yang dikeluarkan. Dengan berinvestasi di reksadana, investor menyerahkan pengelolaan dananya kepada perusahaan reksadana sesuai dengan prospektus. Cara investasi tidak langsung lainnya adalah dengan menyerahkan seluruh kekayaan kepada perusahaan invetasi yang lazim disebut hedge funds atau discretionary funds. Discretionary funds sebetulnya sama dengan mutual funds, hanya pelaksanannya tidak diatur melalui peraturan perundang-undangan sehingga tidak transparan pelaksanaannya bagi masyarakat, yang ada hanyalah kontrak tertutup antara investor dan perusahaan investasi yang ditunjuk untuk mengelola kekayaan investor. Oleh karena itu, hedge funds atau discretionary funds disebut closed-end investment companies dan reksadana disebut open-end investment companies. Dengan demikian, Wealth Management merupakan layanan 
yang menyangkut investment management, tax management, financial management, dan risk management. ${ }^{6}$

Pengelolaan investasi dalam layanan Priority Banking tentu tidak terlepas dari adanya risiko. Produk-produk investasi yang ditawarkan selain terdapat manfaat tetapi juga ada risiko yang mungkin terjadi dari adanya pengelolaan investasi tersebut. Pemberian informasi yang jelas dan transparan menjadi poin penting bagi bank kepada nasabah dalam melakukan pengelolaan investasi khususnya dalam layanan Priority Banking. Hal tersebut menjadi penting untuk dilaksanakan, mengingat dalam pengelolaan investasi tersebut tidak terlepas dari peranan manajer investasi yang khusus untuk mengelola dana nasabah tersebut. Sehingga perlu ditekankan adanya pemberian informasi yang jelas dan transparan kepada nasabah terkait dengan pengeloaan investasi tersebut.

Berdasarkan hal tersebut, perlu diketahui bahwa dengan adanya Pasal 6 huruf $\mathrm{M}$ tersebut bukan berarti bank dalam melakukan layanan/kegiatan perbankan tidak berdasarkan pada peraturan hukum yang berlaku, tetapi harus tetap mematuhi peraturan hukum yang terkait dengan layanan Nasabah Prima atau layanan Priority Banking sebagaimana yang diatur dalam UU Perbankan, Peraturan Bank Indonesia (PBI), Surat Edaran Bank Indonesia (SE BI), Peraturan Otoritas Jasa Keuangan (POJK) dan Surat Edaran Otoritas Jasa Keuangan (SEOJK).

Dalam hal ini otoritas terkait yaitu Bank Indonesia melalui Surat Edaran Bank Indonesia dan Otoritas Jasa Keuangan melalui Peraturan Otoritas Jasa Keuangan memerintahkan secara khusus kepada bank yang ingin melakukan layanan Priority Banking maka harus memenuhi syarat yang telah ditetapkan oleh BI dan OJK khususunya peraturan yang mengatur mengenai layanan Nasabah Prima dan penerapan manajemen risiko bagi bank yang menyelenggarakan layanan Nasabah Prima.

Penerapan prinsip transparansi dan manajamen risiko dalam layanan Priority Banking menjadi hal yang sangat fundamental sebagai dasar penyelenggaraan layanan Priority Banking karena layanan investasi yang

6 Richardus Eko Indrajit dan Richardus Djokopranoto, Wealth Management untuk Penyelenggaraan Perguruan Tinggi, Penerbit Andi, Yogyakarta, 2011, hlm., 30 
ditawarkan oleh layanan Priority Banking ini penuh dengan risiko, sehingga merupakan kewajiban bank untuk menyampaikan informasi yang transparan kepada nasabah mengenai risiko-risiko atas investasi tersebut.

Metode penelitian yang dilakukan dalam penelitian ini adalah menggunakan metode penelitian hukum normatif. Penelitian hukum normatif disebut juga sebagai penelitian doktriner, karena penelitian ini dilakukan atau ditujukan hanya pada peraturan-peraturan yang tertulis atau bahan-bahan hukum yang lain. ${ }^{7}$ Teknik pengumpulan data dilakukan dengan melakukan analisa dengan berdasarkan studi pustaka serta ditunjang dengan wawancara dengan bank swasta nasional di Bandung untuk memperkuat data yang ada.

Berdasarkan hal tersebut, penilitian ini bertujuan untuk mengetahui penerapan prinsip transparansi terhadap peraturan hukum yang terkait dengan layanan Priority Banking dan peranan bank dalam hal pengendalian risiko pada layanan Priority Banking terkait dengan adanya aspek transparansi.

\section{Pembahasan}

\section{Penerapan Prinsip Transparansi Terhadap Peraturan Yang Mengatur Aspek} Transparansi Pada Layanan Priority Banking

Sebelum memahami penerapan Prinsip Transparansi terhadap Peraturan Hukum yang mengatur aspek transparansi pada Layanan Priority Banking, maka perlu dipahami terlebih dahulu secara garis besar mengenai definisi dari layanan Priority Banking. Layanan Priority Banking dalam praktek dunia perbankan merupakan bagian dari Wealth Management. Wealth Management memiliki pengertian sebagai : 8

“ is about serving banking needs of up scale customer."

atau

7 C. Dewi Wulansari, Persoalan Metode Penelitian Dalam Studi Ilmu Hukum, Pro Justitia Tahun XIX Nomor 4 Oktober, Fakultas Hukum Universitas Katolik Parahyangan, Bandung, 2001, hlm., 37

$8 \quad$ Price Waterhouse Coopers, Global Private Banking/Wealth Management Survey, 2005 dalam Ubaidillah Nugraha, Wealth Management, hlm., 12 
“ adalah tentang melayani kebutuhan perbankan berdasarkan skala nasabah.”

Adapun pengertian wealth management secara lebih mendasar dan umum, yaitu ${ }^{9}$ : "wealth management is the process of growing, protecting and managing one's assets through financial product and services."

atau

"Wealth Management adalah proses tumbuh, melindungi dan mengelola aset seseorang melalui produk dan jasa keuangan."

Pada dasarnya investasi merupakan jantung atau tiang utama wealth management. Berdasarkan hal tersebut, tentunya investasi tidak akan terlepas antara manfaat dan risiko terkait dengan setiap produk investasi. Pemberian informasi yang khusus terkait mengatur pada layanan investasi yang diberikan pada layanan Priority Banking belum secara jelas diatur dalam sebuah Peraturan Perundang-undangan. Selain itu, hingga dengan saat ini masih menjadi perdebatan apakah kegiatan wealth management yang dilakukan oleh Bank dan lembaga keuangan memerlukan izin khusus atau hanya merupakan perluasan dari kegiatan bank dan lembaga keuangan yang sudah ada sekarang ini. Kajian sedang dilakukan untuk menentukan apakah jasa wealth management merupakan perluasan jasa manajemen investasi atau bentuk jasa khusus lain yang perlu mendapatkan izin tersendiri. Namun seandainya memerlukan izin tersendiri, maka harus terdapat dasar hukum yang digunakan karena dasar hukum yang khusus mengatur mengenai wealth management belum ada. Sehingga melalui Surat Edaran Bank Indonesia dan Peraturan Otoritas Jasa Keuangan memerintahkan kepada Bank yang menyelenggarakan layanan Investasi dalam layanan Priority Banking untuk dapat menyampaikan informasi secara detail kepada nasabah terkait risiko-risiko investasi pada layanan Priority Banking.

Sehingga dapat disimpulkan bahwa layanan Priority Banking sebagai bagian dari Layanan Wealth Management lebih menekankan kepada pemberian

9 Wealth Management White Papers, diakses dari http://www.Bitpipe.com/tlist/ wealthmanagement.html pada tanggal 24 November 2018, pukul 08.05 
layanan investasi kepada nasabah prioritas. Dalam pelaksanaan kegiatan layanan tersebut, maka bank diwajibkan untuk mematuhi peraturan hukum yang ada terkait dengan pelaksanaan layanan Priority Banking tersebut terutama terkait dengan investasi yang merupakan jantung wealth management. Namun hingga saat ini peraturan hukum yang khusus mengatur mengenai pemberian informasi pada layanan investasi yang diberikan pada layanan Priority Banking belum secara jelas diatur dalam sebuah Peraturan Perundang-undangan, sehingga dalam pelaksanaannya masih mengacu pada peraturan hukum yang terkait dengan penyelenggaraan layanan Nasabah Prioritas.

Atas dasar hal tersebut, penerapan prinsip transparansi menjadi hal yang sangat fundamental di dalam peraturan hukum terkait dengan pemberian layanan Priority Banking khususnya dalam pemberian investasi. Perlu dikaji hal-hal apa sajakah yang tercantum atau diatur dalam peraturan hukum tersebut terutama yang berkaitan dengan aspek transparansi dan keterbukaan informasi khususnya pada pemberian layanan Investasi pada layanan Priority Banking itu sendiri.

Pengertian prinsip transparansi secara umum adalah prinsip yang menjamin akses atau kebebasan bagi setiap orang untuk memperoleh informasi tentang penyelenggaraan pemerintahan, yakni informasi tentang kebijakan, proses pembuatan serta hasil yang dicapai. Menurut Krina, transparansi sebagai prinsip yang menjamin akses atau kebebasan bagi setiap orang untuk memperoleh informasi tentang penyelenggaraan pemerintahan, yakni informasi tentang kebijakan proses pembuatan dan pelaksanaannya serta hasil-hasil yang dicapai. ${ }^{10}$

Transparansi Informasi kepada nasabah yang dimaksud adalah berupa penyampaian mengenai informasi apa saja yang harus diketahui oleh nasabah mengenai suatu produk. Informasi yang harus diketahui nasabah pada produk tidak hanya pada saat nasabah tersebut telah memilih untuk membeli atau mengikuti salah satu produknya tetapi penyampaian informasi yang transparan

10 Loina, Lalolo, Krina P, Indikator dan Alat Ukur Prinsip Akuntanbilitas, Transparansi dan Partisipasi, Sekretariat Good Public Governance, Badan Perencanaan Pembangunan Nasional, Jakarta, 2003, hlm., 30 
harus secara jelas disampaikan oleh staf bank sebelum dilakukannya persetujuan pembelian atau keikutsertaan nasabah atas suatu produk.

Basel Comitte on Banking Supervision III mendefinisikan transparansi sebagai suatu kegiatan untuk menyampaikan informasi yang dapat dipercaya dan tepat waktu kepada publik, sehingga memungkinkan bagi para pengguna informasi untuk memanfaatkannya sesuai dengan kebutuhan. Proses penyampaian informasi tersebut bukanlah hasil dari transparansi, transparansi dapat diraih jika pihak bank mampu menyediakan informasi yang relevan, akurat, tepat waktu dan sesuai dengan definisi sebagaimana yang telah disebutkan. ${ }^{11}$ Selain itu, Basle Comitee on Banking Supervision di Argentina telah mengidentifikasikan 6 (enam) katagori informasi yang perlu diungkapkan kepada masyarakat untuk membantu pencapaian tingkat keterbukaan bank, yaitu adanya a) kinerja keuangan; b) posisi keuangan (termasuk permodalan, solvabilitas dan likuiditas); c) praktik dan strategi manajemen risiko; d) risk exposure (termasuk risiko kredit, risiko pasar, risiko likuiditas, risiko operasional, risiko hukum dan lainnya); e) kebijakan akuntansi; dan f) bisnis dasar, informasi tentang corporate governance dan manajemen. ${ }^{12}$

Dalam literatur Hukum Perbankan (Banking Law), menurut S. Twum dikemukakan bahwa : "The relationship between a banker and his customer is also one of contract. It consist of a general contract and special contracts (such as giving advice on investment to the customer) and other duties, e.g. the banker duty of secry"13

Dari pendapat di atas dapat dilihat bahwa hubungan antara bank dengan nasabah adalah suatu perjanjian (kontrak) yang berarti para pihak dalam hal ini bank dan nasabah mempunyai hak dan kewajiban. Apabila diperhatikan secara seksama UU Perbankan, tidak ditemui ketentuan yang mengatur secara tegas perihal hubungan hukum antara bank dengan nasabahnya. Namun dari beberapa

\footnotetext{
11 M.Umar Chapra, Corporate Governance Lembaga Keuangan Syariah, Bumi Aksara, Jakarta 2008, hlm., 87.

12 Zulkarnaen Sitompul, Transparansi Perbankan: Tantangan 2005, Pilars No. 051/TH VII/27 Desember 2004 - 09 Januari 2005, hlm., 2

13 Sentosa Sembiring, supra no, hlm., 60
} 
ketentuan dapat disimpulkan bahwa hubungan antara bank dengan nasabah diatur oleh suatu perjanjian. Hal ini dapat disimpulkan dari Pasal 1 angka 5 UU Perbankan, yaitu simpanan adalah dana yang dipercayakan oleh masyarakat kepada bank berdasarkan perjanjian penyimpanan dan dalam bentuk giro, deposito, sertifikat deposito, tabungan dan atau untuk lainnya yang dipersamakan dengan itu. ${ }^{14}$ Sebagaimana telah diungkapkan di atas, bahwa hubungan antara bank dan nasabah diatur dalam hukum perjanjian. Ini berarti para pihak dalam hal ini bank sebagai suatu badan usaha dan nasabah baik perorangan maupun badan usaha mempunyai hak dan kewajiban.

Hak dan kewajiban para pihak tersebut harus dilihat dahulu jenis layanan jasa apa yang digunakan oleh nasabah. Hal ini penting karena layanan jasa yang diberikan oleh dunia perbankan sudah demikian luas, sehingga persyaratan yang dicantumkan dalam standar kontrak yang digunakan oleh bank juga bervariasi artinya tergantung dari jenis layanan jasa yang digunakan. Transparansi dalam sektor perbankan ini adalah salah satu hal yang sangat penting dilakukan di dalam sebuah intitusi atau lembaga karena keuangan merupakan sektor yang memiliki risiko yang tinggi.

Adapun indikator yang digunakan dalam penelitian ini adalah indikator prinsip transparansi dalam penelitian ini adalah penyediaan dan akses informasi yang jelas tentang perencanaan, prosedur pelaksanaan dan pertanggungjawaban, adanya musyawarah yang melibatkan nasabah, keterbukaan proses pengelolaan, keterbukaan informasi tentang dokumen pengelolaan, dan adanya relevansi, akurasi dan konsistensi.

Adapun peraturan hukum yang mengatur atau berkaitan aspek transparansi dalam pemberian informasi terkait dengan layanan Priority Banking yaitu:

Undang-Undang Nomor 7 Tahun 1992 sebagaimana telah diubah UndangUndang Nomor 10 Tahun 1998 Tentang Perbankan.

14 Id 
Transparansi informasi tersebut diatur dalam Pasal 29 Ayat 4 UU Perbankan yang menyatakan bahwa: "Untuk kepentingan nasabah, bank wajib menyediakan informasi mengenai kemungkinan terjadinya risiko kerugian sehubungan dengan transaksi nasabah yang dilakukan melalui bank"

Dalam UU Perbankan dijelaskan bahwa salah satu aspek penting dalam melindungi kepentingan nasabah dan dalam rangka pengendalian risiko adalah melalui transparansi informasi terkait produk atau aktivitas bank

\section{Peraturan Bank Indonesia 7/6/PBI/2005 Tentang Transparansi Informasi Produk dan Penggunaan Data Pribadi Nasabah,}

Berdasarkan Pasal 2 Peraturan Bank Indonesia Nomor 7/6/PBI/2005 tanggal 20 Januari 2005 Tentang Transparansi Informasi Produk dan Penggunaan Data Pribadi Nasabah, bahwa pada dasarnya Bank wajib menerapkan transparansi informasi mengenai Produk dan penggunaan Data Pribadi Nasabah. Untuk dapat menerapkan transparansi informasi produk Bank dan penggunaan Data Pribadi Nasabah, maka Bank wajib memiliki kebijakan dan prosedur tertulis. Sedangkan dalam Pasal 4 Ayat 1 dan 2 dijelaskan bahwa Bank wajib menyediakan informasi tertulis dalam bahasa Indonesia secara lengkap dan jelas mengenai karakteristik setiap Produk Bank. Penyampaian informasi tersebut kepada nasabah dapat dilakukan secara tertulis maupun lisan. Bank dilarang memberikan informasi yang menyesatkan (mislead), dan atau tidak etis (misconduct). Dalam Pasal 5 dijelaskan bahwa informasi mengenai karakteristik Produk Bank harus meliputi nama, jenis, manfaat dan risiko, persyaratan dan tata cara penggunaan, biaya-biaya yang melekat, perhitungan bunga atau bagi hasil margin keuntungan, jangka waktu berlakunya, dan penerbit dari produk bank tersebut. Bank wajib memastikan bahwa semua informasi tersebut dapat diperoleh dengan mudah oleh masyarakat.

Peraturan Bank Indonesia Nomor 11/25/PBI/2009 Tentang Perubahan Atas Peraturan Bank Indonesia Nomor 5/PBI/2003 Tentang Penerapan Manajemen Risiko Bagi Bank Umum 
Dalam Pasal 20 Peraturan Bank Indonesia Nomor 11/25/PBI/2009 Tentang Perubahan Atas Peraturan Bank Indonesia Nomor 5/8/PBI/2003 Tentang Penerapan Manajemen Risiko Bagi Bank Umum dijelaskan bahwa salah satu kewajiban Bank dalam menyusun kebijakan dan prosedur untuk mengelola risiko harus mencakup transparansi kepada nasabah sehingga berdasarkan Pasal 20 Ayat 1 dan 2, bank wajib memiliki kebijakan dan prosedur tertulis untuk mengelola risiko yang melekat pada produk atau aktivitas baru bank. Dalam penyusunan kebijakan dan prosedur tertulis tersebut maka berdasarkan Pasal 21, bank wajib menerapkan dan memperhatikan transparansi informasi produk atau aktivitas bank kepada nasabah.

\section{Surat Edaran Bank Indonesia Nomor 13/29/DPNP tanggal 9 Desember 2011} Perihal Penerapan Manajemen Risiko Pada Bank Umum Yang Melakukan Layanan Nasabah Prima

Dalam Surat Edaran Bank Indonesia, dalam melaksanakan LNP dan sebagai bagian dari upaya pemenuhan aspek transparansi, edukasi dan perlindungan nasabah baik yang diatur oleh Bank Indonesia maupun otoritas lainnya, Bank melakukan hal-hal sebagai berikut: ${ }^{15}$

1. Memberikan penjelasan mengenai spesifikasi LNP

a. Bank harus menjelaskan secara tertulis dan lisan mengenai nama/brand name dari LNP, masing-masing kelompok Nasabah Prima dalam LNP dan kriterianya (apabila ada), cakupan layanan produk dan/atau aktivitas yang tersedia untuk ditawarkan kepada Nasabah Prima. Untuk itu, hal-hal yang perlu dijelaskan antara lain:

(1) Spesifikasi dan karakteristik produk dan/atau aktivitas;

(2) Keiistimewaan yang dapat diperoleh sebagai Nasabah Prima; dan

(3) Risiko, tanggung jawab, hak, dan kewajiban baik untuk pihak Bank maupun Nasabah Prima.

15 Lampiran Surat Edaran Nomor 13/29/DPNP Tahun 2011 Perihal Penerapan Manajemen Risiko Pada Bank Umum Yang Melakukan Layanan Nasabah Prima 
b. Dalam hal produk dan/atau aktivitas yang ditawarkan bukan produk dan/atau aktivitas bank yang bersangkutan maka bank wajib:

(1) Menjelaskan bahwa tanggung jawab atas produk dan aktivitas non bank yang ditawarkan oleh atau melalui bank bukan berada pada bank; dan

(2) Menjelaskan kepada Nasabah Prima bahwa produk dan/atau aktivitas tersebut telah memperoleh surat penegasan dan/atau persetujuan dari Bank Indonesia dan otoritas terkait.

c. Pemberian informasi mengenai produk dan/atau aktivitas tidak dapat melebihi kewenangan/izin yang dimiliki bank.

d. Pemberian informasi mengenai produk dan/atau aktivitas tidak dapat menggunakan pengaruh atau tekanan untuk kepentingan bank, grup bank atau pegawai bank.

e. Tidak memberikan informasi yang menyesatkan (misleading) dan/atau yang tidak sesuai dengan norma yang berlaku (misconduct) mengenai produk dan/atau aktivitas yang ditawarkan.

Dengan adanya Peraturan tersebut, maka bank dituntut untuk memberikan penjelasan secara transparan kepada nasabah mengenai spesifikasi Layanan Nasabah Prima terutama informasi mengenai produk, manfaat serta risikonya. Pemberian informasi tersebut tidak boleh menyesatkan sehingga benar-benar harus dilakukan secara transparan.

Peraturan Otoritas Jasa Keuangan Nomor 57/POJK.03/2016 Tentang Penerapan Manajemen Risiko Pada Bank Umum Yang Melakukan Layanan Nasabah Prima.

Dalam Pasal 3 Peraturan Otoritas Jasa Keuangan Nomor 57/POJK.03/2016 Tentang Penerapan Manajemen Risiko Pada Bank Umum Yang Melakukan Layanan Nasabah Prima dijelaskan bahwa:

1) Bank wajib menerapkan manajemen risiko secara umum dalam pelaksanaan LNP. 
2) Bank wajib menerapkan manajemen risiko pada aspek: a) Pendukung keistimewaan layanan; b) Transparansi, edukasi dan perlindungan nasabah.

3) Penerapan manajemen risiko pada aspek pendukung keistimewaan layanan sebagaimana dimaksud pada Ayat 2 huruf a paling sedikit mencakup a) Ketersediaan sumber daya manusia yang memadai sesuai dengan karakteristik dan kompleksitas LNP; b) Prosedur tertulis kegiatan LNP yang mengacu pada ketentuan yang mengatur mengenai penerapan manajemen risiko dan ketentuan yang mengatur mengenai Anti Pencucian Uang dan Pencegahan Pendanaan Terorisme (APU dan PPT); c) Kesesuaian spesifikasi, karakteristik dan risiko dari produk dan/atau aktivitas yang ditawarkan dengan karakteristik dan profil Nasabah Prima; dan d) Ketersediaan teknologi informasi yang memadai.

4) Penerapan manajemen risiko pada aspek transparansi, edukasi dan perlindungan nasabah sebagaimana dimaksud pada ayat (2) huruf b paling sedikit mencakup a) Spesifikasi LNP; b) Kesepakatan tertulis antara Bank dengan Nasabah prima; dan c) Mekanisme untuk memastikan kewenangan pelaku transaksi; dan penyampaian informasi kepada Nasabah Prima mengenai posisi atau eksposur masing-masing Nasabah Prima secara berkala. Bank wajib menatausahakan data, dokumen atau warkat terkait transaksi keuangan dan aktivitas Nasabah Prima dalam LNP.

Atas dasar peraturan tersebut, maka bank diwajibkan untuk menerapkan prinsip Manajemen Risiko sebagai perwujudan Bank dalam menerapkan prinsip transparansi pada Layanan Priority Banking tersebut. Tata kelola yang efektif (Good Corporate Governance) ditetapkan dengan menekankan pada pemahaman risiko dan kemampuan manajemen risiko dan menyelaraskan atau meluruskan selera risiko (risk appetite) dengan kesempatan yang dimiliki perusahaan. ${ }^{16}$

Dari hasil analisa terhadap beberapa Peraturan Hukum mengenai Layanan Priority Banking ini, maka berdasarkan Peraturan Hukum tersebut, setidaknya ada 3 (tiga) fungsi prinsip transparansi yaitu:

16 Endang Siti Arbaina, Penerapan Good Corporate Governance Pada Perbankan Di Indonesia, Jurnalmahasiswa Unesa, Universitas Negeri Surabaya, 2012, hlm., 13 
1. Prinsip Transparansi berfungsi untuk memelihara kepercayaan publik terhadap pasar. ${ }^{17}$ Prinsip keterbukaan atau transparansi ini memiliki peranan penting bagi investor sebelum mengambil keputusan untuk melakukan invetasi karena melalui keterbukaan bisa berbentuk suatu penilaian (judgement) terhadap investasi. ${ }^{18}$ Sehingga investor dapat secara optimal menentukan pilihan terhadap portofolio mereka. ${ }^{19}$

2. Prinsip Transaparansi berfungsi untuk menciptakan mekanisme pasar yang efisien. ${ }^{20}$ Filosofi ini didasarkan pada konstruksi pemberian informasi secara penuh sehingga menciptakan pasar modal yang efisien, yaitu harga saham sepenuhnya merupakan refleksi dari seluruh informasi yang tersedia. ${ }^{21}$ Dengan demikian prinsip keterbukaan dapat berperan dalam meningkatkan supply informasi yang benar agar dapat ditetapkan harga pasar yang akurat. Tanpa informasi peserta pasar tidak dapat mengevaluasi produk-produk Lembaga keuangan,

3. Prinsip Transaparansi penting untuk mencegah penipuan (fraud). Barry A.K Rider menyatakan bahwa "more disclosure will evitably discourage wrongdoing and abuse". Selanjutnya ia menyatakan bahwa dalam pasar keuangan, pendapat tersebut tidak perlu dibuktikan, tetapi lebih banyak bergantung pada informasi apa yang harus diungkapkan dan kepada siapa informasi itu disampaikan. ${ }^{22}$

Secara Das Sollen, produk hukum terkait keterbukaan informasi publik di perbankan dapat menjamin keberlangsungan usaha perbankan dan aksesbilitas

17 Frank H. Eastbrook dan Daniel R. Fischel, The Economic Structure of Corporate Law, dalam Bismar Nasution, Keterbukaan Pasar Modal, Fakultas Hukum, Program Pascasarjana Universitas Indonesia , Jakarta, 2001, hlm., 8

18 D. Brian Hufford, "Dettering Fraud vs Avoiding the "strike suit": Reaching an Approriate Balance”, Brooklyn Law Review, Volume 61, 1995, hlm. 593-594 dalam Bismar Nasution, Ibid, hlm., 8.

19 Frank H. Eastbrook dan Daniel R. Fischel, 2, "Mandatory Disclosure and the Protection of investors", Virgina Law Review, Volume 70, 1984, hlm., 673, dalam Bismar Nasution, Id

20 Lynn A. Stout, The Unifortance of Being Efficient : An Economic Analysis of Stock Market Pricing and Securities Regulation "Michigan Law Review, Volume 87, Desember 1988, hlm., 645, dalam Bismar Nasution, Id, hlm. 8

21 Id, hlm., 8

22 Barry A. K Rider "Global Trens in Securities Regulation: The Changing Legal Climate ", Dickinson Jurnal of International Law, Spring, 195, hlm. 514 dalam Bismar Nasution, Id, hlm. 9 
informasi publik sebagaimana diamanatkan dalam konstitusi. Namun secara Das Sein masih terdapat sejumlah permasalahan antara lain batasan informasi yang dapat diakses publik, mekanisme permintaan informasi publik di perbankan, mekanisme pengukuran informasi berbasis manajemen risiko, penyusunan matriks informasi yang dapat/tidak dapat diakses publik dan sebagainya. ${ }^{23}$ Kualitas pelayanan menjadi penting karena dalam industri perbankan, kepuasan nasabah sangat bergantung pada kualitas layanan yang diberikan. ${ }^{24}$

Terkait dengan prinsip transparansi dan peraturan hukum tersebut mengenai layanan Priority Banking dan dikaitkan dengan indikator atau parameter apakah peraturan hukum yang ada telah sesuai dengan prinsip transparansi, maka perlu dianalisa lebih lanjut. Berdasarkan indikator yang pertama, yaitu penyediaan dan akses informasi yang jelas tentang perencanaan, prosedur pelaksanaan dan pertanggungjawaban. Pada dasarnya akses informasi terkait perencanaan, prosedur pelaksanaan dan pertanggungjawaban harus tersedia dan mudah diakses serta jelas. Sehingga nasabah dapat mengetahui secara transparan mengenai bagaimana perencanaan, prosedur pelaksanaan dan pertanggungjawaban dari bank.

Dalam peraturan hukum tersebut di atas masih belum menunjukan secara jelas bagaimana penyediaan dan akses informasi yang jelas tentang perencanaan, prosedur pelaksanaan dan pertanggungjawaban terkait risiko investasi pada Layanan Priority Banking. Dalam memberikan informasi terkait dengan produk dan/atau aktivitas Layanan Priority Banking, pihak bank menjelaskan dan memberikan informasi secara detail mengenai fitur, manfaat serta risiko dari produk dan/aktivitas itu sendiri disesuaikan dengan profil dari nasabah. Nasabah akan diberikan penjelasan terkait dengan profil dari nasabah itu sendiri dan risiko yang mungkin akan terjadi. Bank akan melakukan analisa terkait profil nasabah apakah nasabah tersebut bersifat agresif atau semi agresif yang dianalisa dalam

23 Prima Satya Irianto dan Budi Ispriyarso, Keterbukaan Informasi Publik Di Perbankan, Jurnal Law Reform, Volume 2 Nomor 2, Program Studi Magister Ilmu Hukum, Fakultas Hukum Universitas Diponegoro, Semarang, 2016, hlm., 2

24 Indra Prabhata, Pengaruh Kualitas Pelayanan dan Kualitas Produk Kredit UKM Terhadap Loyalitas Nasabah PT. BPR Kerta Raharja Bandung, Transparansi Jurnal Ilmiah Ilmu Administrasi, Volume 9 Nomor 01, 2017, hlm., 4 
sebuah portfolio. Dalam peraturan-peraturan hukum yang terkait dengan layanan Priority Banking tersebut hanya dijelaskan mengenai kewajiban bank untuk menyediakan informasi mengenai karakteristik produk dan/atau aktivitas perbankan, hal-hal apa saja yang wajib dicantumkan dalam kebijakan internal bank sebagai perwujudan dari manajemen risiko dan penerapan prinsip transparansi, hak dan kewajiban dari para pihak serta kemungkinan terjadinya risiko kerugian sehubungan dengan transaksi nasabah yang dilakukan melalui bank.

Indikator yang kedua adalah adanya musyarawah yang melibatkan nasabah. Maksud dari musyawarah dalam hal ini adalah, bahwa bank harus melibatkan nasabah dalam proses pengambilan keputusan dalam pemilihan produk dan/atau aktivitas perbankan, termasuk pula penjelasan mengenai manfaat dan risiko atas produk dan/atau aktivitas perbankan tersebut. Setelah dilakukan penelitian, pihak bank telah berusaha untuk menjelaskan informasi secara jelas dan detail mengenai manfaat dan risiko terkait produk dan aktivitas layanan investasi yang terdapat pada layanan Priority Banking. Namun dari sisi nasabah mengatakan bahwa informasi terkait produk dan aktivitas layanan investasi tersebut memang dijelaskan oleh pihak bank, namun terkadang penyampaian informasi tersebut masih kurang dipahami oleh nasabah baik itu penjelasan secara lisan maupun tertulis. Sehingga nasabah merasa kurang bisa melakukan diskusi dengan pihak bank karena penyampaian informasi tersebut yang terkesan kurang mudah dipahami. Perlu diketahui bahwa sebelum memutuskan untuk berinvestasi pada layanan Priority Banking, maka harus ada kesepakatan terlebih dahulu dari nasabah. Bank sebelumnya sudah menjelaskan terkait dengan risiko dan manfaat secara seimbang atas produk investasi yang dipilih oleh nasabah. Jika sudah dijelakan secara detail, biasanya nasabah jarang ada yang komplain bila terjadi kerugian. Intinya bahwa solusi penerapan prinsip kehati-hatian menjadi yang utama karena harus disesuaikan dengan profil nasabah. Kalau misalkan nasabah tidak bisa mengambil risiko tersebut, maka bank tidak akan menawarkan produk yang bersifat high risk tersebut. 
Indikator yang ketiga adalah keterbukaan proses pengelolaan. Pemberian informasi yang transparan tidak hanya dalam pemberian informasi terkait manfaat dan risiko atas produk dan/atau aktivitas perbankan saja, tetapi juga dalam proses pengelolaan dari produk dan/atau aktivitas perbankan tersebut juga harus dapat mudah diketahui dan transparan kepada nasabah. Tidak boleh ada hal yang ditutupi-tutupi dalam proses pengelolaannya, sehingga nasabah mengetahui proses tersebut secara transparan. Berdasarkan hasil penelitian, bahwa penulis tidak mendapatkan data mengenai bagaimana proses pengelolaan mengenai layanan investasi tersebut. Penulis hanya dijelaskan bahwa dalam hal pengelolaan investasi yang dilakukan oleh bank, maka bank akan melakukan review secara berkala melalui portfolio nasabah. Hal tersebut akan disampaikan kepada nasabah melalui sales call yang dilakukan 2 (dua) minggu sekali terkait dengan posisi terakhir investasi yang dilakukan apakah rugi atau untung.

Perlu diketahui bahwa posisi bank adalah sebagai penjual/perantara. Namun bank juga memiliki kewajiban untuk memberikan informasi secara detail kepada nasabah mengenai manfaat dan risiko dari produk investasi yang ditawarkan. Dalam hal ini terdapat manajer investasi yang memberikan fund fact sheet dan salinan prospektus kepada nasabah. Pengelolaan investasi dilakukan oleh perusahaan manajer investasi. Kedudukan bank melakukan analisa market dan analisa produk. Investasi harus disesuaikan dengan profil risiko nasabah itu sendiri, apakah cocok atau tidak cocok investasi tersebut untuk dipilih oleh nasabah. Hal tersebut terdapat dalam kontrak/portfolio.

Namun atas hal tersebut tidak dijelaskan bagaimana keterbukaan proses pengelolaan tersebut. Di dalam Pasal 29 Undang-Undang Perbankan juga tidak menjelaskan mengenai kewajiban bank untuk memberikan keterbukaan dalam proses pengelolaan. Dari sisi nasabah pun hanya disampaikan mengenai hasil pengelolaan investasi dalam bentuk fund fact sheet namun tidak dijelaskan bagaimana proses pengelolaan dana investasi tersebut.

Indikator yang keempat adalah keterbukaan informasi tentang dokumen pengelolaan. Dalam hal ini yang dimaksud dengan dokumen pengelolaan adalah setiap produk dan/atau aktivitas perbankan wajib dijelaskan secara tertulis dalam 
dokumen secara transparan dan jelas. Pada dasarnya bahwa bank wajib memberikan laporan yang efektif. Agar laporan keuangan menjadi lebih efektif dan tidak menyesatkan, maka seluruh informasi yang relevan harus disajikan dengan cara tidak memihak, dapat dipahami dan tepat waktu. Inilah yang dikenal dengan prinsip pengungkapan penuh (full disclosure principle). ${ }^{25}$ Nasabah harus mengetahui apa yang menjadi hak dan kewajiban, manfaat dan risiko atas produk/aktivitas yang dipilih oleh nasabah. Dokumen tersebut harus diberikan kepada nasabah, bank dalam hal ini harus memberikan salinan dokumen tersebut sebagai wujud dari prinsip transparansi tersebut. Dari hasil penelitian yang dilakukan, bahwa bank memberikan fund fact sheet dan salinan prospektus kepada nasabah sebagai laporan rutin atas hasil pengelolaan investasi yang dilakukan oleh pihak manajer investasi. Investasi yang dipilih oleh nasabah harus disesuaikan dengan profil product, risk product, dan risk customer. Investasi harus disesuaikan dengan profil risiko nasabah itu sendiri, apakah cocok atau tidak cocok investasi tersebut untuk dipilih oleh nasabah. Hal tersebut terdapat dalam kontrak/portfolio. Selain itu, di dalam fund fact sheet tersebut tentu hanya dijelaskan mengenai hasilnya saja, dan tidak dijelaskan secara detail mengenai proses pengelolaannya. Berdasarkan hasil penelitian dengan nasabah, bahwa bila risiko atas investasi tersebut terjadi, maka pihak bank akan memberikan informasi melalui sales call dan tidak berupa laporan tertulis.

Indikator kelima adalah Relevansi, Akurasi dan Konsistensi. Dalam setiap informasi yang diberikan harus ada relevansi atau keterkaitan antara proses pengelolaan dengan dokumen tersebut. Selain itu, pemberian informasi harus akurat dan tidak menimbulkan salah tafsir. Pemberian informasi juga harus bersifat konsisten berdasarkan pada peraturan yang berlaku. Pada dasarnya dalam melakukan layanan Priority Banking harus memiliki kebijakan internal yang didasarkan pada peraturan-peraturan hukum yang terkait dengan Layanan Priority Banking. Adanya risiko terhadap setiap investasi yang dilakukan nasabah, maka Bank Indonesia dan Otoritas Jasa Keuangan memerintahkan bank untuk

25 Herry, Teori Akuntansi, Kencana Prenada Media Group, Jakarta, 2009, hlm., 114 
mematuhi ketentuan-ketentuan yang terkait dengan layanan Priority Banking tersebut terutama dalam penerapan manajemen risiko sebagai wujud dari pengendalian risiko. Dalam peraturan hukum yang terkait dengan layanan Priority Banking tersebut menekankan adanya penerapan prinsip transparansi sebagai wujud dari penerapan manajemen risiko dan pengendalian risiko dalam layanan Priority Banking. Berdasarkan hasil penelitian yang dilakukan bahwa bank dalam memberikan informasi kepada nasabah telah mengikuti peraturan hukum serta kebijakan internal yang terkait dengan layanan Priority Banking. Pada dasarnya, kebijakan internal tersebut telah memenuhi semua persyaratan yang ditentukan dalam peraturan dari Bank Indonesia dan Otoritas Jasa Keuangan tersebut.

\section{Peranan Bank Dalam Pengendalian Risiko Pada Layanan Priority Banking Terkait Aspek Transparansi.}

Pada dasarnya, Bank dalam investasi dalam layanan Priority Banking adalah sebagai Agen Penjual (Perantara) sehingga bank tidak bertanggung jawab secara langsung terhadap investasi yang mengalami kerugian. Investasi dilakukan oleh Fund Manager. Fund Manager tersebut akan memberikan salinan prospektus kepada nasabah berdasarkan Fund Fact Sheet yang berisi laporan dana kelolaan nasabah di Fund Manager tersebut. Perlu diketahui bahwa, hingga saat ini tidak ada peraturan hukum yang menjelaskan bahwa bank bisa bertindak sebagai pemberi layanan investasi. Sehingga BI dan OJK memerintahkan kepada bank untuk dapat bersikap transparan dalam memberikan informasi kepada nasabah karena investasi pada dasarnya adalah layanan yang penuh dengan risiko.

Investasi tidak terlepas dari risiko-risiko yang mungkin dihadapi oleh nasabah dalam hal ini adalah nasabah prioritas. Pada dasarnya, bank tidak bertujuan untuk menghindari risiko. Sebaliknya, akan mengambil risiko yang sepadan dengan pengembaliannya sebatas risiko yang dapat diterima (risk appetite) bank. Bank dapat menerima risiko yang mampu diidentifikasi, dipahami, diukur, dipantau dan dikendalikan. Tentunya agar pemberian layanan dan/atau produk perbankan dapat dilaksanakan secara konsisten dan berdasarkan pada asas perbankan yang sehat, maka diperlukan adanya suatu pedoman layanan 
kegiatan bank dalam hal ini adalah layanan Priority Banking yang dijadikan acuan bagi seluruh unit atau divisi di bank yang terkait dengan layanan Priority Banking. Pada dasarnya pedoman layanan Priority Banking memiliki tujuan yaitu:

1. Sebagai penjabaran dan kebijakan layanan Priority Banking yang diselaraskan dengan Business Plan Bank.

2. Sebagai pedoman pelaksanaan kegiatan layanan Priority Banking bagi seluruh unit kerja di Bank.

3. Sebagai acuan standar pengawasan dan pengendalian internal pada semua tahapan dalam proses pemberian layanan Priority Banking

4. Untuk membentuk disiplin dan pemberian standar pelayanan yang sama bagi seluruh unit kerja Layanan Priority Banking sehingga terbentuk adanya budaya perbankan yang sehat sebagai bagian dari profesionalisme bankir.

5. Menjamin adanya pengawasan yang memadai dalam setiap tahapan proses layanan Priority Banking.

Semakin kompleksnya produk dan aktivitas Bank maka risiko yang dihadapi Bank akan semakin meningkat. Peningkatan risiko yang dihadapi Bank perlu diimbangi dengan kualitas penerapan manajemen risiko yang memadai. Bahwa transparansi merupakan salah satu aspek yang perlu diperhatikan dalam pengendalian risiko yang dihadapi oleh Bank. Selain itu peningkatan kualitas penerapan manajemen risiko akan mendukung efektivitas kerangka pengawasan Bank berbasis risiko.

Upaya peningkatan kualitas penerapan manajemen risiko dimaksud tidak hanya ditujukan bagi kepentingan Bank tetapi juga bagi kepentingan nasabah. Salah satu aspek penting dalam melindungi kepentingan nasabah dan dalam rangka pengendalian risiko adalah transparansi informasi terkait produk atau aktivitas Bank.

Pada dasarnya, pengertian manajemen risiko dapat diartikan sebagai manajemen risiko dapat didefinisikan sebagai suatu metode logis dan sistematis dalam identifikasi, kuantifikasi, menentukan sikap, menetapkan solusi serta melakukan monitor dan melaporkan risiko yang berlangsung pada setiap aktivitas 
atau proses. ${ }^{26}$ Pengertian lain manajemen risiko adalah serangkaian prosedur dan metodologi yang digunakan untuk mengidentifikasi, mengukur, memantau dan mengendalikan risiko yang timbul dari kegiatan usaha bank. ${ }^{27}$ Selain itu, manajemen risiko adalah suatu bidang ilmu yang membahas tentang bagaimana suatu organisasi menerapkan ukuran dalam memetakan berbagai permasalahan yang ada dengan menempatkn berbagai pendekatan manajemen secara komprehensif dan sistematis. ${ }^{28}$

Bank Indonesia memberikan pengertian risiko yang tertuang dalam PBI Nomor 5/8/PBI/2003 Tentang Penerapan Manajemen Risiko Bagi Bank Umum sebagai potensi terjadinya suatu peristiwa (events) yang dapat menimbulkan kerugian Bank. Berdasarkan pengertian tersebut dapat disimpulkan bahwa risiko adalah peluang dari kemungkinan terjadinya peristiwa yang tidak diinginkan atau merugikan bagi perusahaan atau lembaga maupun bagi orang perorangan.

Pelaksanaan manajemen risiko dilakukan dengan mengacu kepada international best practices terbaik yang terbagi dalam 3 (tiga) kategori. Pertama, pengendalian risiko secara first line of defense yang dilakukan oleh unit kerja yang melaksanakan proses bisnis. Kedua, pengendalian risiko secara second line of defense dilakukan oleh unit kerja yang memiliki fungsi manajemen risiko dan independen dari unit kerja yang melaksanakan proses bisnis. Ketiga, pengendalian risiko secara third line of defense dilakukan oleh unit kerja yang melaksanakan fungsi audit internal guna memastikan kegiatan pengendalian risiko dilaksanakan secara efektif. ${ }^{29}$

Terkait dengan manajemen risiko yang dilakukan oleh bank, maka tidak terlepas dari adanya penerapan Prinsip Mengenal Nasabah (Know Your Customer). Prinsip mengenal nasabah adalah prinsip yang diterapkan bank untuk mengetahui

26 Ferry N Idroes, Manajemen Risiko Perbankan: Dalam Konteks Kesepakatan Basel dan Peraturan Bank Indonesia, Graha Ilmu, Yogyakarta, 2006, hlm., 5.

27 Pasal 1 Ayat 3 Peraturan Bank Indonesia Nomor 5/8/PBI/2003 Tentang Penerapan Manajemen Risiko Bagi Bank Umum.

28 Irfan Fahmi, Manajemen Risiko, Teori, Kasus dan Solusi, Alfabeta, Bandung, 2011, hlm., 2

29 Bank Indonesia, Manajemen Risiko dan Pengendalian Internal, diakses dari https://www.bi.go.id/id/tentang-bi/governance/process/manajemenrisiko/Contents/Default.aspx pada hari Rabu, 24 Juli 2019 
identitas nasabah, memantau kegiatan transaksi nasabah termasuk pelaporan transaksi yang mencurigakan. ${ }^{30}$ Bank akan berusaha untuk membangun dan mempertahankan hubungan jangka panjang dengan para nasabahnya. Hal mendasar bagi manajemen risiko adalah kemampuan bank untuk para nasabah memiliki profil nasabah yang baik. selain itu, nasabah harus mempunyai karakter yang baik, yang menjaga standar etika bisnis dan selalu memenuhi kewajiban nasabah secara tepat waktu dan profesional. Fasilitas dalam bentuk layanan investasi dalam layanan Priority Banking hanya boleh diberikan jika ada pemahaman yang baik dan penilaian risiko yang terkait dengan pemberian layanan tersebut dan sejajar dengan strategi portfolio nasabah. Dengan adanya prinsip tersebut, maka pemahaman secara mendalam kepada calon nasabah prioritas/nasabah prioritas wajib dituliskan secara jelas dengan mengacu kepada ketentuan (internal maupun eksternal bank) yang berlaku. Sehingga pada dasarnya bank harus menghindari konsentrasi risiko yang berlebihan pada portfolio yang dapat mengakibatkan kerugian pada layanan Priority Banking di luar risk appetite. Bank harus mengutamakan tim yang berbasis pada manajemen risiko dengan dual control/check and balances yang tepat sehingga tidak ada pejabat bank yang bertindak sendiri dan dapat menyebabkan bank menanggung risiko tambahan atas layanan Priority Banking di luar risk appetite.

Sedangkan dalam Prinsip Kehati-hatian (prudent banking principle) adalah suatu asas atau prinsip yang menyatakan bahwa bank dalam menjalankan fungsi dan kegiatan usahanya wajib bersikap hati-hati (prudent) dalam rangka melindungi dana masyarakat yang dipercayakan padanya. Hal ini didasarkan pada Pasal 2 Undang-Undang Perbankan, bahwa pada dasarnya perbankan Indonesia dalam melakukan usahanya berasaskan demokrasi ekonomi dengan menggunakan prinsip kehati-hatian. Mengenai prinsip kehati-hatian secara eksplisit diatur dalam Pasal 29 angka 2, 3 dan 4 Undang-Undang Perbankan.

30 Pasal 1 Ayat 2 Peraturan Bank Indonesia Nomor 5/21/PBI/2003 Tentang Perubahan Kedua Atas Peraturan Bank Indonesia Nomor 3/10/PBI/2001 Tentang Penerapan Prinsip Mengenal Nasabah (Know Your Customer Principle) 
Pasal 29

(1) Pembinaan dan pengawasan bank dilakukan oleh Bank Indonesia.

(2) Bank wajib memelihara tingkat kesehatan bank sesuai dengan ketentuan kecukupan modal, kualitas aset, kualitas manajemen, likuiditas, rentabilitas, solvabilitas, dan aspek lain yang berhubungan dengan usaha bank, dan wajib melakukan kegiatan usaha sesuai dengan prinsip kehati-hatian.

(3) Dalam memberikan kredit atau pembiayaan berdasarkan Prinsip Syariah dan melakukan kegiatan usaha lainnya, bank wajib menempuh cara-cara yang tidak merugikan bank dan kepentingan nasabah yang mempercayakan dananya kepada bank.

(4) Untuk kepentingan nasabah, bank wajib menyediakan informasi mengenai kemungkinan timbulnya risiko kerugian sehubungan dengan transaksi nasabah yang dilakukan melalui bank.

(5) Ketentuan yang wajib dipenuhi oleh bank sebagaimana dimaksud dalam ayat (2), ayat (3) dan ayat (4) ditetapkan oleh Bank Indonesia.

Pasal 29 Undang-Undang Perbankan ini merupakan pasal yang termasuk dalam ruang lingkup pembinaan dan pengawasan. Artinya, ketentuan prudent banking sendiri merupakan bagian dari pembinaan dan pengawasan bank. Apa yang dimaksud dengan prinsip kehati-hatian, oleh Undang-Undang Perbankan sama sekali tidak dijelaskan baik pada bagian ketentuan maupun dalam penjelasannya. Undang-Undang Perbankan hanya menyebutkan istilah dan ruang lingkupnya saja sebaimana dijelaskan dalam Pasal 29 ayat 2, 3, dan 4 tersebut diatas. Dalam pasal tersebut juga dijelaskan bahwa bank wajib menjalankan usaha sesuai dengan prinsip kehati-hatian. Dalam pengertian, bank wajib untuk tetap senantiasa memelihara tingkat kesehatan bank, kecukupan modal, kualitas aset, kualitas manajemen, likuiditas, rentabilitas, dan aspek lain yang berhubungan dengan usaha bank.

Berdasarkan hal tersebut, dalam rangka mendukung atau menjamin terlaksananya proses pengambilan keputusan dalam pengelolaan bank yang sesuai dengan prinsip kehati-hatian maka bank wajib memiliki dan menerapkan sistem pengawasan interen dalam bentuk self regulations. Selain itu, dalam ketentuan prinsip kehati-hatian bank ini adalah adanya kewajiban bagi bank menyediakan informasi mengenai kemungkinan timbulnya risiko kerugian sehubungan dengan transaksi nasabah yang dilakukan melalui bank sebagaimana 
dijelaskan dalam Pasal 29 ayat 4. Ketentuan ini menunjukan bahwa bank benarbenar memiliki tanggung jawab terhadap para nasabahnya. Hal ini penting bagi bank dalam rangka menjaga hubungan baik dan berkelanjutan dengan nasabahnya. Apabila nasabah dirugikan, maka akan berdampak pada hilangnya kepercayaan kepada bank karena pada dasarnya hubungan bank dengan nasabah adalah sebagai hubungan kepercayaan (fiduciary relationship).

Pada dasarnya kewajiban bank dalam menyusun kebijakan dan prosedur untuk mengelola risiko harus mencakup transparansi kepada nasabah sebagaimana yang dijelaskan pada Peraturan Bank Indonesia Nomor 11/25/PBI/2009 Tentang Perubahan Atas Peraturan Bank Indonesia Nomor 5/8/PBI/2003 Tentang Penerapan Manajemen Risiko. Sedangkan pengendalian risiko secara khusus pada layanan Priority Banking diatur dalam Surat Edaran Bank Indonesia Nomor 13/29/DPNP tanggal 9 Desember 2011 Tentang Penerapan Manajemen Risiko Pada Bank Umum Yang Melakukan Layanan Nasabah Prima dan Peraturan Otoritas Jasa Keuangan Nomor 57/POJK.03/2016 Tentang Penerapan Manajemen Risiko Pada Bank Umum Yang Melakukan Layanan Nasabah Prima. Kedua peraturan tersebut menekankan bahwa pengendalian risiko bagi bank dalam investasi dalam layanan Priority Banking karena terdapat potensi meningkatnya profil risiko perbankan, khususnya risiko operasional, risiko hukum dan risiko reputasi dalam praktek penyediaan layanan perbankan dengan keiistimewaan tertentu kepada suatu segmen nasabah tertentu. Sehingga berdasarkan hal tersebut BI dan OJK memerintahkan bank yang menyediakan layanan Priority Banking wajib menerapkan manajemen risiko pada layanan investasi yang dilakukan pada layanan Priority Banking karena pada dasarnya investasi tidak terlepas dari risiko-risiko.

Penerapan Manajemen Risiko (Risk Management) dalam penerapan keterbukaan informasi di perbankan dilaksanakan dengan urutan identifikasi kegiatan, perencanaan, pelaksanaaan, monitoring dan evaluasi. Pembuatan sistematika penerapan ini guna memudahan pengendalian risiko yang berpotensi terjadi selama kegiatan operasional bank terkait pelaksanaan keterbukaan informasi bank. Kegiatan yang dijadikan contoh adalah kegiatan penyusunan 
Laporan Tahunan Bank (Annual Report) mulai dari tahap identifikasi kegiatan sampai evaluasi kegiatan, yang terdiri dari:

1) Identifikasi Kegiatan Penetapan batasan risiko yang ditetapkan oleh bank (Risk Tolerance) yang tertuang dalam Rencana Bisnis Bank, pengaturan secara ketat sesuai dengan 8 (delapan) jenis risiko dan batasan risiko yang ditetapkan oleh bank (Risk Tolerance) yang dilakukan oleh bank karena hal ini dapat mempengaruhi komposisi neraca bank.

2) Perencanaan Kegiatan Pada aspek perencanaan kegiatan, bank menyusun rencana kegiatan dengan memperhatikan sejumlah instrumen yang diidentifikasi dari sejumlah potensi risiko yang muncul dari tahap identifikasi risiko yang disusun dengan unit Risk Management. Bank berkewajiban melaksanakan kegiatan penyusunan Laporan Tahunan secara mandiri dan/atau berkerja sama dengan mitra kerja atau vendor yang berpengalaman sesuai dengan timeline serta kerangka acuan kerja yang dibuat oleh bank. Pelaksanaan kegiatan penyusunan Laporan Tahunan selain dilaksanakan oleh unit Risk Management, juga harus didukung oleh fungsi lain dalam memasok kebutuhan atau konten di dalamnya.

Penerapan manajemen risiko tersebut terwujud dalam Tata Kelola Perusahaan Yang Baik (Good Corporate Governance) yang dijalankan perbankan dengan membuka akses informasi publik dengan menggunakan berbagai macam media antara lain website, laporan tahunan, laporan kinerja operasional dan sebagainya. Unit kerja yang menjalankan komunikasi internal maupun komunikasi eksternal (shareholder) dan/atau komunikasi eksternal (pemerintah/masyarakat) ini diwajibkan untuk melakukan implementasi manajemen risiko dalam kegiatan operasional dalam rangka mewujudkan pemberdasyaan dan perlindungan konsumen pada jasa perbankan.

\section{Penutup}

Penerapan prinsip Transparansi terhadap Peraturan Hukum yang mengatur aspek transparansi pada layanan Priority Banking bahwa pada dasarnya 
penerapan prinsip transparansi menjadi hal yang sangat fundamental dalam pemberian informasi terkait dengan produk dan/atau aktivitas bank dalam hal ini adalah layanan investasi pada layanan Priority Banking. Terkait dengan risiko dari investasi yang dilakukan oleh layanan Priority Banking, maka ketaatan bank belum sepenuhnya sesuai dengan aturan yang diperintahkan oleh Bank Indonesia dan Otoritas Jasa Keuangan. Hal tersebut terlihat bahwa bank kurang transparan dalam memberikan informasi terkait dengan layanan Priority Banking. Selain itu, peranan bank dalam hal pengendalian risiko pada Layanan Priority Banking terkait dengan adanya aspek transparansi bahwa pada dasarnya setiap produk investasi memiliki risiko yang tinggi. Kewajiban bank dalam hal pengendalian risiko harus menerapkan manajemen risiko pada setiap kebijakan internal yang dimiliki oleh bank yang menyelenggarakan Layanan Priority Banking.

\section{Daftar Pustaka}

\section{Buku:}

Bismar Nasution, Keterbukaan Pasar Modal, Fakultas Hukum, Program Pascasarjana Universitas Indonesia , Jakarta, 2001

Ferry N. Idroes, Manajemen Risiko Perbankan: Dalam Konteks Kesepakatan Basel dan Peraturan Bank Indonesia, Graha Ilmu, Yogyakarta, 2006

Hermansyah, Hukum Perbankan Nasional Indonesia, Edisi Kedua, Kencana Prenada Media Group, Jakarta, 2005

Herry, Teori Akuntansi, Kencana Prenada Media Group, Jakarta, 2009

Irfan Fahmi, Manajemen Risiko, Teori, Kasus dan Solusi, Alfabeta, Bandung, 2011 Loina, Lalolo, Krina P, Indikator dan Alat Ukur Prinsip Akuntanbilitas, Transparansi dan Partisipasi, Sekretariat Good Public Governance, Badan Perencanaan Pembangunan Nasional, Jakarta, 2003

M.Umar Chapra, Corporate Governance Lembaga Keuangan Syariah, Bumi Aksara, Jakarta 2008 
Price Waterhouse Coopers, Global Private Banking/Wealth Management Survey, 2005.

Richardus Eko Indrajit dan Richardus Djokopranoto, Wealth Management untuk Penyelenggaraan Perguruan Tinggi, Penerbit Andi, Yogyakarta, 2011

Sentosa Sembiring, Hukum Perbankan, Mandar Maju, Bandung, 2008

\section{Peraturan Perundang-Undangan}

Undang-Undang Dasar Republik Indonesia Tahun 1945.

Undang-Undang Nomor 7 Tahun 1992 sebegaimana telah diubah berdasarkan Undang-Undang Nomor 10 Tahun 1998 Tentang Perbankan.

Peraturan Bank Indonesia Nomor 7/6/PBI/2005 Tentang Transparansi Informasi Produk dan Penggunaan Data Pribadi Nasabah.

Peraturan Bank Indonesia Nomor 11/25/PBI/2009 Tentang Perubahan Atas Peraturan Bank Indonesia Nomor 5/PBI/2003 Tentang Penerapan Manajemen Risiko Bagi Bank Umum.

Surat Edaran Bank Indonesia Nomor 13/29/DPNP tanggal 9 Desember 2011 Perihal Penerapan Manajemen Risiko Pada Bank Umum yang Melakukan Layanan Nasabah Prima.

Peraturan Otoritas Jasa Keuangan Nomor 57/POJK.03/2016 Tentang Penerapan Manajemen Risiko Pada Bank Umum Yang Melakukan Layanan Nasabah Prima.

\section{Jurnal}

Barry A. K Rider "Global Trens in Securities Regulation: The Changing Legal Climate ", Dickinson Jurnal of International Law, Spring, 1995

Brian Hufford, "Dettering Fraud vs Avoiding the "strike suit" : Reaching an Approriate Balance", Brooklyn Law Review, Volume 61, 1995

C. Dewi Wulansari, Persoalan Metode Penelitian Dalam Studi Ilmu Hukum, Pro Justitia Tahun XIX Nomor 4 Oktober, Fakultas Hukum Universitas Katolik Parahyangan, Bandung, 2001

Endang Siti Arbaina, Penerapan Good Corporate Governance Pada Perbankan Di Indonesia, Jurnalmahasiswa Unesa, Universitas Negeri Surabaya, 2012

Frank H. Eastbrook dan Daniel R. Fischel, 2, "Mandatory Disclosure and the Protection of investors", Virgina Law Review, Volume 70, 1984

Indra Prabhata, Pengaruh Kualitas Pelayanan dan Kualitas Produk Kredit UKM Terhadap Loyalitas Nasabah PT. BPR Kerta Raharja Bandung, Transparansi Jurnal Ilmiah Ilmu Administrasi, Volume 9 Nomor 01, 2017

Lynn A. Stout, The Unifortance of Being Efficient : An Economic Analysis of Stock Market Pricing and Securities Regulation "Michigan Law Review, Volume 87, Desember 1988,

Prima Satya Irianto dan Budi Ispriyarso, Keterbukaan Informasi Publik Di Perbankan, Jurnal Law Reform, Volume 2 Nomor 2, Program Studi Magister Ilmu Hukum, Fakultas Hukum Universitas Diponegoro, Semarang, 2016

Renniwaty Siringoringo, Analisis Fungsi Intermediasi Perbankan Indonesia (Studi Kasus Bank Umum Konvesional yang Tercatat di BEI Periode 2012-2016), Jurnal Inspirasi Bisnis \& Manajemen Vol 1 (2) 2017, 135-144 
Zulkarnaen Sitompul, Transparansi Perbankan: Tantangan 2005, Pilars No. 051/TH VII/27 Desember 2004 - 09 Januari 2005

Situs:

Bank Indonesia, Manajemen Risiko dan Pengendalian Internal, diakses https://www.bi.go.id/id/tentang-bi/governance/process/manajemenrisiko/Contents/Default.aspx 